\section{特別融 演}

\author{
北陸の医勘物学 一過去・現在・末来一 \\ 近薜力王至（金沢大・医・寄生虫） Medical Zoology \\ in Hokuriku -The history and future- Kondo, K.
}

北陸地方の医助物学研究の基は，加加落の医学的閶心事 に負うところが大きい，病因を「ムシ」といった時代，

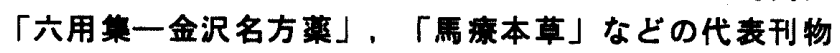

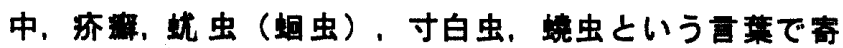

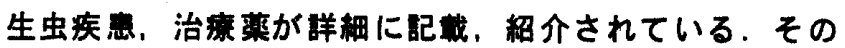
後空白時代があるものの，明治に入り病原客生虫，媒介 功物の形柋，分颣学上の位置が明確になるに従い，北陸 からも桂田方士郎，中川幸展など世界的な学者を墔出， その後における医功物学研究に大きな影零を与えた，更 に、整戦に至る間はフィラリア，マラリア，広飭致頭条 虫，苪原媒介助物の啁㚗，研究も盛んに行われ，北陸に おける医县物学研究の黎明期ともいえよう，戦後，北陸 にも次々と医科大学が新設、関係機間との連㩲，教育・ 研究の隆盛時を迎え，多くの研究成果が報告されたが，

一般得管青生虫，媒介助物の激減により，新しい研究テ 一マが要求されるようになった，一方，国除社会への要 望に応え，途上国への医療協力の道を開くなど，進展が みられる，我々のなすべき道は，先䢖の輝かしい業䋶を 事け粴き，末来へと飽くなき研究・対策を続けていくの が，我々に眯せられた責務と考えるべきであろう。

2 環境変化と寄生虫病 2 .人口增加 - 国際化·疾 病構造の変化と寄生虫病. 井関基弘（大阪市大・医・医 動物) Influence of the world population increase, globalization of human life, and changes of disease structure on human parasitoses. M. ISEKI

現在の世界人口の增加は年間 1 億人近いが、その約 95 \%は途上国で、そのまた約半数は最贫国の多いアフリカ と南アジアでおこっている。人口增加は発電用ダムや潅 溉用水路の建設、鉱物 - 森林資源の開発、農耕地開拓を もたらし、化石燃料の大量消粠は地球の温暖化を招く。 これらはマラリアや住血吸虫などのベクター生息地を拡 げる大きな要因になる。また、途上国では都市部への急 激な人口集中がおこり、都市のスラム化、衛生環境の悪 化が進む。南北、南南の所得格差の拡大、民族紛争によ る難民の増加、交通機関の発達と企業の国際化の進展な どはヒトや生鮮食料品の国際的大量移動を促す。これら は全て奇生虫病患者の増加と世界的拡散の要因となり、 日本では世界に分布するあらゆる種類の輸入奇生虫病へ の対応が迫られる。

エイズの流行も急激に進んでいるが、免疫不全患者の 増加という疾病構造の変化は日和見奇生虫症を增大させ るばかりでなく、従来とは異なった病像を示す難治性の 原虫症を增加させている。新しい診断・治療法の開発が 要求される。

\section{シンポジム}

1 「棵境変化と寄生虫病」

1 .はじめに

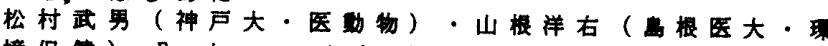

境保侥) Environmental changes and parasitoses.

1. Introduction

T. MATSUMURA \& Y. YAMANE

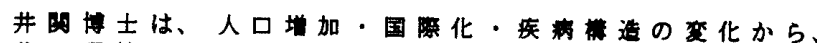

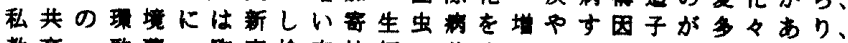

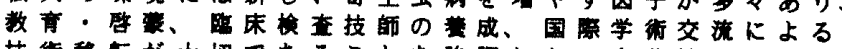

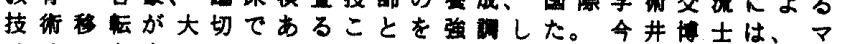

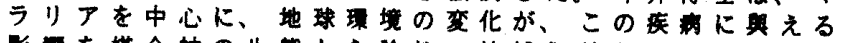

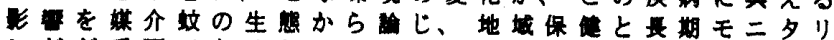
ングが直要であるとした。行天肺士は我国の肺㖟虫鿊の

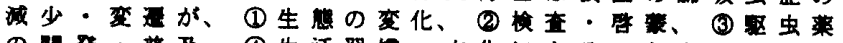

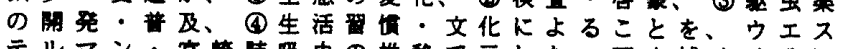

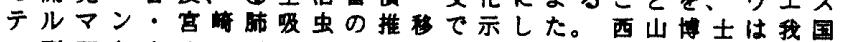

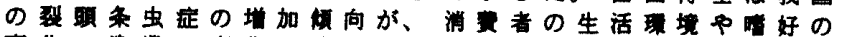

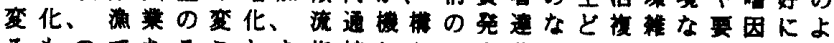
るものであることを指揞した。安博士は、地球理境破

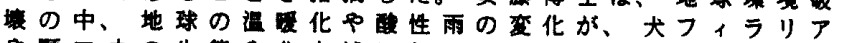

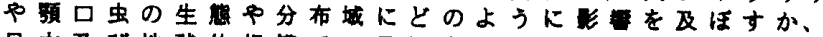
日本及び地球的规模ての予濑を䲽みた。特别発吉として

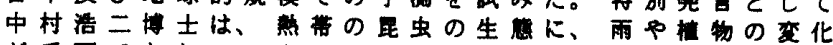
が重要であり、ミクロ的な热需研究の亩点を示した。赤

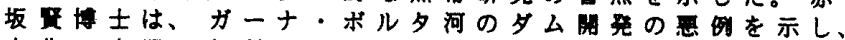

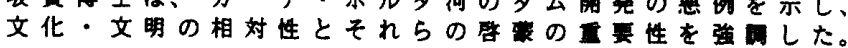

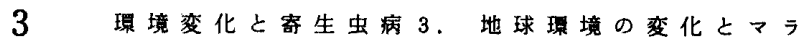
リ $\mathrm{s}$ 今井長兵街（大阪市環境科研） Environmental changes and parasitoses. 3. Global environmental change and malaria Chobei Imai

温暧化など地球環境の変化とマラリア流行との関わり を vectorial capacity, $C=m a^{2} p^{n} /(-1 n p) の$ 概念を用い て榆封した。温暖化ガスによる界温は摡ね0.9〜1.8 ${ }^{\circ} \mathrm{C}$ と 予测され、较体内でのマラリア原虫の発育所要日数 $\mathrm{n}$ を 短樎する。温暖化仕幼生期の短縮を通して蚊の年間世代 数を增加させるが、低緗度地方における降水量の純減を あたらし、発生源を若干樎小する方向にす斯くと予测さ れる。したがって、温暖化は必ずしる四の增加に直結し ないが、媒介妏の種や個体群によっては心が增加する可 能性は十分にある。nの短縮は媒介可能な妏の平均余命 $\mathrm{p} n /\left(\begin{array}{ll}-1 \mathrm{n} & \mathrm{p}\end{array}\right)$ を延長するが、延長の度合いは纹の生存事 $\mathrm{p}$ が高いと小さく、低いと大きくなる。したがって、昇温 によるpの低下がある籍囲内に留まれば、温暖化は媒介 可能な蚁の平均余命を延長する。以上から、温暖化がc を大きくし、マラリア流行を促進する可能性が示唆され る。一方、砂漠化は妏の発生源縮小を通して流行を抑生 し、蒊帯林破壤は森林マラリアとヒトとの接触の促進を 通じて流行を促進するでろう。また、温暖化による海 面上昇は海岸マラリアの流行を促進する可能性がある。 